How to cite this article:

Abdul Ghani, A., I. M. (2020) Challenges for legal education in the era of I.R.4.0. UUM Journal of Legal Studies, 11(2), 27-51. https://doi.org/10.32890/uumjls. 11.2.2020.7731

\title{
CHALLENGES FOR LEGAL EDUCATION IN THE ERA OF I.R.4.0
}

\author{
Ida Madieha Abdul Ghani Azmi \\ Civil Law Department \\ International Islamic University Malaysia \\ idamadieha@iium.edu.my
}

Received:26/12/2019 Revised: 12/4/2020 Accepted: 24/4/2020 Published: 31/7/2020

\begin{abstract}
The formulation of the National Policy on Industrial Revolution 4.0 (IR4.0) and the Internet of things signals the readiness of the Malaysian government to come up with the necessary policy framework for the digitalised era. It has been said that universities' curriculum structure and instructional design must also be revisited to ready the graduates to face the onslaught of the technological revolution. Through content analysis of relevant literature, this paper analysed the myriad ways in which legal education has been impacted by IR4.0 both in terms of the 'body of knowledge' as well as the 'skill sets' required for law students to survive in the era of autonomous systems. The paper was structured to first explain the concept of IR4.0 and how some national countries leverage digital technology to improve their economy or facilitate social transformation. The paper proceeded with a discussion of how autonomous systems, artificial intelligence and data analysis can enhance the instructional design of teaching and researching law. In terms of the body of knowledge, most of the legal principles drawn for the brick and mortar environment are no longer relevant in the IR4.0 era. The paper reveals that the traditional method that focuses on the training of law graduates to think like a lawyer by understanding the reasoning in the judgement of cases or the preparation of conveyancing and court documents are no longer relevant in the IR4.0 era as these activities could easily
\end{abstract}


be undertaken by bots. Instead, law students should be imparted with a multiplicity of human skills that cannot be performed by autonomous systems such as those involving conscience, high level thinking and emotions such as mediation, negotiation, counselling, court prosecution, advocacy, witness examination, plea mitigation as well as social skills, resource management skills, technical skills and most importantly system skills.

Keywords: Industrial Revolution 4.0, legal education, body of knowledge, skill sets.

\section{INTRODUCTION}

The rapid growth of interconnectivity, automation, machine-learning and real-time data have transformed our daily lives, activities, tasks and processes into integrated digitally-enabled lives. These revolutionary advances are disrupting traditional ways of doing business and if harnessed to the fullest will increase productivity and foster economic growth. Naturally, Malaysia, like the rest of the world, has formulated national policies and earmarked strategic initiatives to develop its digital innovation-led growth economy and this is reflected in her Industrial Revolution 4.0 (IR4.0) and the National Policy on the Internet of Things (IoT).

The Malaysian Policy on IR4.0 describes the IR4.0 revolution as "a future innovation that is building up to deal with the lack of human resource (like human labour) in some skills". In this environment, we can foresee "the fusion of digitalization with traditional industrial processes which lead to intelligent value chains and a product lifecycle from the initial development of a product, to the manufacturing, assembly, and eventual product delivery and maintenance and recycling". By so doing, Malaysia is aiming to transform its industrial processes using the nine key technologies that underpin IR4.0 which consist of autonomous robots, simulation, horizontal and vertical system integration, the industrial Internet of Things, cyber-security, the cloud, additive manufacturing, augmented reality and big data analysis. In the policy, Malaysia has identified 5 sectors as the main focus of Industry 4.0, i.e. electrical and electronics, machinery and equipment, chemical, medical devices, aerospace and other sectors. In simple terms, IR4.0 refers to an intelligent industry in which the entire chain of production is autonomous through the use of machines embedded with wireless connectivity and sensors controlled by an 
intelligent system capable of autonomous decision-making. What it essentially boils down to is the use of advanced digital technologies for industrial purposes. In order to support industries to embrace these technologies, the policy identified several challenges. Not surprisingly, legal knowledge and legal services are involved in the entire eco-system from the funding stage up to the infrastructure and regulatory framework. As a result, we can identify a whole range of issues and challenges than can arise ranging from the ownership of intellectual properties due to inter-connectivity and informationsharing along the supply chain and the potential exposure to cyberthreats with increased connectivity and new technologies such as the Internet of Things.

As the Internet of Things (IoT) is the backbone of IR4.0, a complementary national policy on IoT has also been framed. In this policy which is known as the National Internet of Things (IoT) Strategic Roadmap: A Summary, Malaysia aims to be the premier regional IoT development hub. IoT is defined as "an intelligent interactivity between humans and things to exchange information and knowledge for new value creation" (MIMOS, 2015). In the policy, Malaysia aspires to create a national eco-system to enable the proliferation of use and industrialization of IoT as a new source of economic growth. The aim of the roadmap is not only to create new jobs but also to enable the exploitation of local patents.

IoT describes the phenomena of digital connectivity between devices and humans and between devices themselves. IoT envisages a situation where four pillars are connected and integrated with each other, i.e. people, process, data and things. IoT will transform all economic, industrial and everyday processes through the connectivity between humans and electronics. The list of things that can potentially be connected to the Internet is virtually endless. It includes items like smart phones, books, household devices such as television monitors, water meters, c.c.tv camera, and even food, medicines and wearable items with sensors such as smart glasses, watches etc.

This paper will address the following three points: First, the evolution of IR4.0 through its basic concepts will be traced. In doing so, the Malaysian national reports will be looked at and compared with the initiatives introduced by other countries to have a sense of where Malaysia is in comparison to other countries. Second, the 
legal implications of IR4.0 on the legal profession will be examined. Third, the disruptions that the digital revolution has caused to legal education in Malaysia will be explored.

\section{NATIONAL COUNTRIES’ RESPONSES}

National countries are responding to the coming of the digital transformation in their national policies in a myriad of ways. Unlike Malaysia that is aiming to leverage digital technology disruption to increase the efficiency of industrial processes, other countries like Singapore and Japan have a more forward-looking plan in integrating the entire nation-building process into a digitallyembedded platform.

In Singapore this comes in the form of the smart nation which was launched in 2014 by the then PM Lee Kuan Yew (Smart Nation and Digital Government Office, 2018). In this national plan, Singapore aims to embrace digital technology to the fullest. In order to achieve this noble objective, Singapore has laid out key initiatives to leverage upon the power of digital solutions to empower and improve human lives by pre-empting the inevitable transformations of key domains such as health, transport, urban solutions, finance and education. Under these initiatives, Singapore aims to make homes safer, more comfortable and more sustainable with the use of sensors and smart systems. The idea is to move the whole nation forward using digital technology in all processes and activities; either through their daily activities, government activities, businesses and manufacturing processes. At the backbone of this digitally connected nation is a strong cyber law framework which would be supported by the National Cyber-security Strategy 2016 and the Cyber-security Act 2018. More fundamentally, to harness the digital processes to the fullest, there is a need to build a digitally-ready workforce to seize new opportunities, and the Singapore government has invested money in equipping its citizens with the right mindset and skills for the future economy.

Japan is equally aiming to embrace digitalization for nation building in an agenda called Society 5.0 (Fukuyama, 2018). 'Society 5.0' has been defined as "a human-centered society that balances economic advancement with the resolution of social problems by a system that highly integrates cyberspace and physical space". The goal of 
Society 5.0 is to leverage on digitalisation to provide for all human solutions in order to achieve balanced economic development, conserve the environment, and solve social issues.

Japan aims to be the first country in the world to create this human-centered society. Unlike IR4.0 which began with the age of mechanization and steam power, Society 5.0 goes all the way back to the hunter-gatherer societies of ages past. In many ways, Society 5.0 is one stage ahead of IR4.0, where not only things and systems are connected to cyberspace, but people are also an effective means of resolving issues in society. Whilst IR4.0 focuses on production, Society 5.0 seeks to put humans at the centre of innovation. The idea is to embrace connectivity as a means to provide daily solutions to human activities. For such an interface to take place between all actors, human and non-human, the standardization of devices and systems must be developed (Carraz \& Harayama, 2018).

Similarly, the Australian Chamber of Commerce and Industry, has also outlined certain strategic initiatives to tap into the positive force of advanced technologies to advance the country's economy, and this is known as the digital economy. In the report entitled, The Digital Economy: Opening up the Conversation, it was highlighted that among the things required for the regulators would be laws that enable and support digital economy (through digital infrastructure, standards and regulations, trust, confidence and security), (Australian Chamber of Commerce, 2017). In the report, the term Digital economy is used to describe the range of economic and social activities that are enabled by information and communications technologies (Australian Chamber of Commerce, 2017). From the angle of the government and business, certain areas of competitive strength must be built up in order to enhance digital readiness and capability and drive productivity. To support connectivity and interoperability, a single harmonized international standard on protocols and devices needs to be developed. To instil trust, confidence and security, the judiciary must also play a role by cracking down on any forms of cyber threats (including malware, botnets, denial-of-service attacks), scams (including identity theft, phishing, spam and privacy risks) and fortifying cyber security (by taking action against hacking, cracking, and critical infrastructure attacks) that arise as a result of social media, smart devices, wearable gadgets and the Internet of Things. 
The Malaysian IR4.0 policy essentially aims to transform industrial processes using the latest digital technologies in the 5 focused-upon sectors. The policy stops short of adopting the digitalization process in all realms of activities or nation building like other nations. A fully realised IR 4.0 would undertake the transformation of all processes and activities in digital form and this would entail the replacement of human labour with autonomous systems and robots. As envisaged by Klaus Schwab (World Economic Forum, n.d), the founder and executive chairman of the World Economic Forum 2016, there are five persistent worries that plague the advent of the industrial revolution, i.e. organizations might be unable to adapt, governments could fail to employ and regulate new technologies to capture their benefit, shifting powers will create important security concerns, inequality may grow and societies may fragment.

Never has there been a topic that has taken the whole world by surprise save for IR4.0. Business models and regulators must prepare themselves for this oncoming wave of disruptive modernisation and thus respond dynamically. As the custodians of the future, and, with the power that we currently hold, tomorrow must come today in our minds.

These technological advances are transforming not only the way we operate business, daily activities, government functions and business practices but also legal practice and legal norms. In many ways, the way the legal schools are run must equally be impacted as well.

\section{AUTONOMOUS SYSTEM, LEGAL EDUCATION AND LEGAL PROFESSION}

Whilst we cannot help but be distracted with the legal, social and business changes as a result of the advances of information and communication technology, we cannot close our eyes to the impact of digitalization, autonomous systems run by artificial intelligence and big data in respect of the legal profession and legal education.

We are now wading through unchartered territory and many of the legal implications of some of the usages of these technological devices may still be unknown to us. Nineteen years ago, the University of Chicago organized a Law School Roundtable on the theme 'Legal Reasoning and Artificial Intelligence: How Computers 
"Think" like Lawyers. In this roundtable, a group of US law professors explored the legal implications of artificial intelligence in legal practice (Ashley, Branting, Margolis and Sunstein, 2001). Of particular concern was the use of certain computational models of analytical reasoning used for inductive legal reasoning. The bots comprised two main components, i.e. a repository of knowledge representation and an inference mechanism. The bots were programmed to effectively draw information from the repository of legal information and offer solutions to a given legal problem. What the program does is essentially generate legal arguments and even generate alternative interpretations of cases. It is capable of sieving through voluminous legal content and draw analogies from decided cases to offer possible decisions for new problems, a task which is typically done by a human lawyer but at a fraction of the time.

The value of computational models to legal practice and legal education is obvious. The system is of substantial value to law students who have to comprehend, digest and draw legal reasoning from hundreds of material cases, a skill that law schools have tried to ingrain in their legal method courses through inductive reasoning which is core to lawyering and judicial decision-making. It was mooted that these programs will ensure a systematic and consistent inductive reasoning; It will also be able to give more objective predictive outcomes compared to human reasoning which is often coloured by bias, prejudice and emotions.

With advances in machine-learning, artificial intelligence can substantially assist humans in intellectual and thinking functions. The most obvious benefit of AI is in the domain of routine legal work such as drafting and documentation. It is in these repetitive, mundane and routine matters that Richard Susskind, in his 1996 book, The Future of Law: The Challenges of Information Technology, predicts a drastically changing traditional legal practice. Firstly, many routine legal services would be automated and, secondly, we may see in the future the proliferation of new legal expert systems in the form of bots. Contracts would no longer be in the form of mere static texts, rather they will be in the form of smart contracts that are capable of self-execution and being stored on the block chain which nobody controls and therefore, everyone can trust (Raskin, 2017). Secondly, the Internet can also serve as a powerful distribution mechanism for legal expertise where legal practice can be broken down into different tasks that can be outsourced to different entities, turning 
legal practice into a web-based delivery of legal services much like the production chain in the global value chain environment.

The development of artificial intelligence that is able to perform some of these legal tasks would be a gold mine for the legal profession as there is no assistance in the form of a computer system that is capable of thinking like lawyers. On this note, Ashley (Ashley et al., 2001) persuasively argues that gone were the days when decisionmakers had the luxury of time as they have to come up with quick responses to resolve problems posed by the digital revolution. There is a need to anticipate future problems and provide possible solutions in the form of legal, technical, and social devices.

Klaus Schwab further added at the World Economic Forum, in The Fourth Industrial Revolution- What it Means and How to Respond, that the top-down approach typically experienced by policy-makers would not be dynamic enough to catch the rapid pace of change caused by IR4.0. The legislators and regulators must adapt to the pace of change, by continuously adapting themselves to the new frontier and learning fast to understand the changing eco-system that they are expected to regulate. A close collaboration between the government and regulatory agencies and business and civil society is imperative for this to work (World Economic Forum, n.d)."

The judiciary has an even more substantial role in developing new legal principles whilst at the same time preserving the interests of consumers and the public at large. As laws passed by Parliament tend to be reactive and not prospective to technological developments, many issues are not anticipated and hence, are left unregulated. It is then the task of the judiciary to fill the gaps in the legal and regulatory framework by creating, modifying or extending the existing legal norms to cover new issues heretofore unknown. Judicial activism is the last saviour in the legal eco-chain process. However, in countries where judicial activism is bridled by precedents and legislative instruments, placing full dependence on judicial activism as an instrument of progress is often an exercise in futility.

Whilst it has often been said that the autonomous system could come in handy for routine and repetitive tasks, the predictive function of the system could also assist the judiciary in decision-making. In the US, the use of artificial intelligence to impose sentencing is not unheard of. The Supreme Court of the state of Wisconsin, in 
State of Wisconsin v Eric L. Loomis (No 2015AP157-CR) was faced with an appeal on a trial court sentencing of an accused which was arrived at with the facilitation of a program known as COMPAS1. The COMPAS1 program, through its algorithm, predicted that the accused was a high risk to the community because of his propensity to reoffend. As the circuit court placed the need to protect the public and the rehabilitation of the offender as the primary criteria, the court eventually imposed the accused with a higher sentence compared to other first offenders. When the competency of COMPAS1 was challenged by the defence counsel as being a mere algorithm-led prediction, the court defended its decision to use the system on the basis that the system provided relevant, valid, and accurate information about an offender's risks to reoffend and about the rehabilitation needs of the offender. In that sense, the role of AI is no longer to just sift through materials but to also form assessments in its predictions. Although it is easy to blame the system if a judgement turns out to be flawed, in reality it will be the judge who will be in charge of rationalizing the data and summarily using that data to make a judgment.

The Supreme Court further noted that the prediction was not based on irrelevant criteria, much like the human thinking processes in determining the sentencing of offenders. The program not only considered the individual's age at the time of the first offence but also considered a number of other relevant factors such as the current age, criminal history including arrest history, placement, and types of crimes. The defence counsel further challenged the legitimacy of using such predictive algorithms which could be said to have offended due process. On this, the court substantiated the use of evidencebased risk assessment tools which would be able to eliminate some of the subjectivities that arise from human intuition, perhaps making the decision more accurate and systematic in comparison to human logic. In the eventual summation, the Supreme Court found that the Circuit Court had properly exercised its discretion in sentencing, did not rely on improper factors, and did not violate due process and sentencing on inaccurate information.

Despite the interest the decision has sparked on the reasonableness of using algorithm-led prediction for sentencing, the implications it has on legal practice and legal education is enormous (BrennanMarquez, 2019). In The Future of the Professions: How Technology Will Transform the Work of Human Experts, Professor Susskind 
(2015), warns that the body of content that currently makes up the bulk of the legal curriculum, consisting not only of substantive law but also procedural laws, is set to face massive changes as a result of technological disruption. He believes that law schools should not only aim to prepare students for legal practice but to also prepare them for a whole range of law-related careers in order to produce forward-looking lawyers that will be able to innovate a legal framework relevant for the future rather than one based on $18^{\text {th }}$ century principles.

In the same tone, Madison (2018) asserts that law schools must incorporate new critical analytical skills and, most fundamentally, technology-deployment skills, and management and business skills. He posits that perhaps legal education should no longer be centred exclusively in law schools. The focus of law schools should no longer be solely to prepare lawyers for the bar exam. As quite a number of these students do not practice law or will practice only for a short period of time, the preoccupation should not be solely to prepare law graduates for practice but to prepare them for a wide range of skills in order to improve their adaptability.

If law schools are not able to adapt themselves to be more relevant in the information age, their prognosis may be quite gloomy. Campbell (2014) predicts the end of the traditional law school which depends on old doctrinal analyses as the teaching pedagogy because that method of teaching will no longer be relevant in the era of AI as the task of retrieving legal principles and precedents could be replaced by AI. This old method depends on doctrinal analysis that requires law students to search for relevant case laws, process and comprehend them, and retrieve the relevant legal principles or ratio decidendi and obiter dicta by way of applying and distinguishing principles. The old view that law graduates should be trained to think like lawyers, i.e. to understand the rationale of judgement to be able to carry out his profession effectively, is no longer relevant in the information era. He believes that the perennial problem of the strained relationship between law schools and the profession will become more serious in the information era as the type of skill sets required will be different. He stresses that in order to survive in this era, lawyers may need to gain other complex skill sets that only partially involve law, e.g. compliance, mediation, legal process management and e-discovery. He emphasizes that law schools must place less emphasis on how to think like lawyers and stress 
more on how to serve society. In order to ensure that students are connected with real world problems, there must be more clinical and experiential learning in the legal curriculum.

Alarie, Niblett and Yoon (2017) assert that the legal profession is not immune from disruption by advanced technologies. New software tools could substantially assist expert human judgment typically committed by human lawyers. Activated by advances in natural language processing and machine- learning, some of the tasks normally undertaken by lawyers could be replaced by AI. At the same time, the nature of legal practice which is traditionally clientcentred and billable on the basis of man hours would be tremendously transformed. This machine-learning would be capable of processing a large amount of information which could substantially assist in the discovery processes which are routinely undertaken by junior associates. It would be able to assist in identifying cases, statutory provisions as well as secondary materials most relevant to litigation. Routine forms and documents could be created by the bots at the click of a finger. Machine-learning tools could also assist in deciding litigation strategy via its capacity to expeditiously sift through large volumes of information and offer the best option based on algorithmic predictions. The ensuing issue is whether the opinion produced by autonomous systems would be considered valid legal opinions, as they are not given by human lawyers. Regardless, the challenge over the legitimacy of these bots ignores the fact that with these tools lawyers would be able to make objective and accurate predictions on many issues. Previously, lawyers needed to use computers to conduct keyword searches through Lexis Nexis. However, they still had to read, process and comprehend the voluminous materials by themselves or with the help of a team of lawyers. Now, it is possible for the autonomous system to peruse millions of documents and frame legal advice and even predict outcomes in a shorter time frame than the human mind.

Simshaw (2018) stresses that law graduates need to adapt to the disruption caused by the information era. He discusses how bots, automated systems and predictive analysis are changing the way lawyers provide legal services. Although not all tasks can be automated, AI has made an impact in document review, e-discovery, legal research, and in some circumstances, outcome prediction. It has been said that a system known as ROSS intelligence is the world's first artificially intelligent attorney capable of reading pages 
of information per second, able to glean through laws, cases and secondary sources, whilst simultaneously keeping up-to-date with legal developments locally and across the globe.

One positive development from the autonomous system is that it might increase access to justice by lowering costs and expanding services to untapped markets. These bots would be able to serve a bigger clientele base as it will be able to be accessed anywhere in the world. As with any other online diagnosis platform, the ensuing worry is whether these tools can be used by lawyers without breaching the ethics of the legal profession, particularly the special fiduciary relationship between a lawyer and a client. We can also envisage a wide range of possible ethical repercussions, ranging from the competency of the system, the confidentiality of the communication with clients, the supervision of third parties in the context of outsourcing tasks, exercising independent judgement and candid advice as well as possible conflict with former clients. These issues are not easily resolved and as suggested by Sinshaw (2018) should be embedded in the architecture of the bots itself so that the autonomous systems that are created are ethically friendly if not ethically correct.

In reality, the service rendered by bots cannot be legitimately considered legal practice. Traditionally, to effectively render legal service, one must be considered as being admitted as a member of the legal profession, i.e. one has to be a qualified person for the purpose of the Legal Qualifying Act. Autonomous systems cannot be considered a qualified person and cannot be accorded the full status of Advocate and Solicitor in Malaysia. In that sense, the legal fraternity should be able to impose restrictions on what types of autonomous systems should be recognised by the legal profession and which should not. However, there is a great danger that these tools could be resorted to by users as self-help remedies, much like online medical sites that give advice on diagnosis and medication based on symptoms provided by Internet users. What would then be the impeding liabilities of the developers of these autonomous systems if the advice turned out to be untrue, false, defamatory or downright criminal? With the disparity in Internet penetration in the rural and urban areas, there is also a grave danger that rural people would be inhibited in using the services of the bots. An autonomous system therefore, creates gaps in access to justice and the outcome would be the same with the use of the physical court system. More 
fundamentally, it has to be recognized that AI cannot replicate all human capabilities; therefore, at best it should not be considered as a replacement for humans but as assistants to human lawyers.

The discussion now moves to consider the body of knowledge and skill sets required for law schools to produce law graduates that would be relevant in the IR4.0 era.

\section{LEGAL CURRICULUM FOR THE 22 ${ }^{\mathrm{ND}}$ CENTURY}

Our world today is not only a world of challenges but also a world where we must learn to be resilient and dynamic at the same time. We are continuously faced with unexpected occurrences and sudden shocks. The challenge now is to continue pursuing critical goals while these events occur, learning to adapt to changing contexts as we go along. We need to embark upon a broader horizon, that is to say to look at the future of the new global frontier, to look at the future of legal education in the era of IR4.0.

As AI is set to replace many of the routine and repetitive tasks performed by human lawyers, the old traditional workplace arrangement, i.e. having permanent, full-time employees will change in the future with more and more tasks being able to be outsourced (Payton, 2017). On this note, Professor Jane den Hollander, in a report prepared by the committee for economic development of Australia, warned of the danger of complacency of law schools and how this could be disastrous (CEDA, 2015). In a national report, the Australian government predicted that, in the future, it is highly probable that $40 \%$ of the Australian labour market, or five million jobs, could be replaced by computers in the next couple of decades. Due to automation, traditional roles along the line of jobs that we know would no longer exist.

The education sector has been identified by Deloitte as one of the 'long dues big bang' industries in its analysis of the impact of digital disruption on industries (subject to major transformation but over a longer time period) (Deloitte Digital, 2015). Banerjee and Belson (2015) added that there is a need to move digital education from content (1.0) to connections (2.0). In this second wave of digital education, the emphasis is that education must move beyond the classroom. Whilst the first wave of digital education focused on 
creating, sharing and accessing instructional content in digital forms, including online courses, digital libraries, games and apps, the 2nd wave entails integrated digital education eco-systems, studentlearning life cycles, and technology solutions.

Another scholar, Penprase (2018), posits that in the wake of IR4.0 higher education institutions must refocus their curriculums to emphasize more on training that can help shape wisdom and skill. There must be a shift in emphasis from routine tasks into the development of the habits of mind and the capacity for creativity. Educational institutions must emphasize more on soft skills such as career navigation, work ethics and innovation. In IR4.0, the focus on human social skills such as persuasion and emotional intelligence will be greatly emphasised. This requires a drastic reconsideration of the curriculum within higher education. There is the high possibility that there might be a mismatch of skills in the future workplace based on IR4.0. The need for reskilling becomes imperative and reskilling and retraining must be considered a priority. Higher educational institutions must not think of producing human labour as an immediate aim but instead must prepare students to be lifelong learners as they may need to catch up with relevant skills (The World Economic Forum, 2016).

In legal practice, it is those human skills which make possible subjective judgment and assessment which are the essence of litigation. It is emotion, empathy and compassion which distinguish a person from a bot. The strength of human beings in this regard should not be seen as failings of human nature. Whilst lawyers can take advantage of AI assistance in repetitive and routine matters, complex tasks such as mediation, negotiation, court prosecution, advocacy, witness examination, plea mitigation and family counselling still require humans, just to name a few tasks that are human-centric.

Let us examine whether the law curriculum set by the MQA has all the right ingredients to survive the IR4.0 era. Under the MQA Programme Standards: Law and Shariah Law (MQA, 2015), the following are the programme standards for Law and Shariah:

i. illustrate an understanding of the fundamentals of legal principles, concepts and theories and authoritative sources of law in Law or Shariah Law; 
ii. perform critical, analytical and problem- solving skills with the ability to apply relevant principles, concepts and theories in Law or Shariah Law to a given situation;

iii. demonstrate an adequate level of proficiency in required languages such as Bahasa Malaysia, English Language and Arabic Language (whichever is suitable) and practical skills including communication (oral and written), negotiation, client counselling and interview, mooting and research skills;

iv. explain international development in Law or Shariah Law;

v. build an understanding of the working environment of Law or Shariah Law such as in the courts, law firms, corporations and legal aid centres;

vi. display an awareness, and as far as practicable, internalise the ethics and etiquettes of the profession, as well as moral obligations to the community and humanity;

vii. apply managerial and entrepreneurial skills to establish career opportunities in the legal or Shariah profession;

viii. apply relevant skills for lifelong learning and continuing professional development;

ix. demonstrate understanding of the rule of law and social justice; and

$\mathrm{x}$. demonstrate knowledge of jurisdictional disputes between the Shariah Court and the Civil Court.

Under the standards, the law curriculum must not only contain the required body of knowledge but also the required skill set needed for a lawyer. In terms of skills, the MQA standards identified as crucial for law graduates are as follows:

\begin{tabular}{cccc}
\hline Advocacy & $\begin{array}{c}\text { Alternative } \\
\text { Dispute } \\
\text { Resolution }\end{array}$ & Application & Drafting \\
\hline $\begin{array}{c}\text { Ethic and } \\
\text { Professional } \\
\text { Conduct }\end{array}$ & $\begin{array}{c}\text { Interviewing } \\
\text { and Advising }\end{array}$ & $\begin{array}{c}\text { Knowledge and } \\
\text { Understanding }\end{array}$ & Litigation Process \\
\hline
\end{tabular}

(continued) 


\begin{tabular}{cccc}
\hline $\begin{array}{c}\text { Office } \\
\text { Management }\end{array}$ & Opinion & Oral & Problem Solving \\
Research & Self- & Communication & \\
& Management & $\begin{array}{c}\text { Thinking and } \\
\text { Analytical } \\
\text { Skills }\end{array}$ & $\begin{array}{c}\text { Written } \\
\text { Communication }\end{array}$ \\
\hline
\end{tabular}

Studies like Christensen and Kift (2000) identified the following six desirable capabilities of a law graduate:

Discipline Knowledge

Ethical Aattitude

Problem-Solving and Reasoning

Information Literacy

Interpersonal Focus
Graduates will possess detailed and comprehensive knowledge of Australian legal principles and statutory regimes, knowledge of legal systems and influences outside Australia, an understanding of the latter's relationship with the Australian legal system and a fundamental knowledge of extra legal factors impinging upon substantive law.

Ethical Attitude graduates will possess a sense of community and professional responsibility and will be able to identify and offer appropriate solutions to ethical dilemmas.

Graduates will possess critical thinking and problem-solving skills, which enable effective analysis, evaluation and creative resolution of legal problems.

Information Literacy graduates will be able to use current technologies and effective strategies for the retrieval, evaluation and creative use of relevant information as lifelong learners.

Graduates will be able to work both independently and as a productive member of a team, practice critical reflection and creative thinking, be socially responsible and inclusive, and be able to work effectively and sensitively within the global community in continually changing environments. 
In comparison, the core work related skills identified by the World Economic Forum (2016) as critically required for the future workforce in IR4.0 are as tabulated below:

\begin{tabular}{|c|c|c|c|}
\hline \multirow{2}{*}{$\begin{array}{c}\text { Abilities } \\
\text { Cognitive } \\
\text { Abilities }\end{array}$} & \multirow{2}{*}{$\begin{array}{c}\text { Basic Skills } \\
\text { Content Skills }\end{array}$} & \multicolumn{2}{|c|}{ Cross-Functional Skills } \\
\hline & & Social Skills & $\begin{array}{c}\text { Resource } \\
\text { Management } \\
\text { Skills }\end{array}$ \\
\hline $\begin{array}{l}\text { Cognitive } \\
\text { Flexibility }\end{array}$ & Active Learning & $\begin{array}{c}\text { Coordinating with } \\
\text { Others }\end{array}$ & $\begin{array}{c}\text { Management } \\
\text { of Financial } \\
\text { Resources }\end{array}$ \\
\hline Creativity & Oral Expression & $\begin{array}{l}\text { Emotional } \\
\text { Intelligence }\end{array}$ & $\begin{array}{c}\text { Management } \\
\text { of Material } \\
\text { Resources }\end{array}$ \\
\hline Logical Reasoning & Reading & Negotiation & $\begin{array}{c}\text { People } \\
\text { Management }\end{array}$ \\
\hline $\begin{array}{l}\text { Problem } \\
\text { Sensitivity }\end{array}$ & Comprehension & Persuasion & $\begin{array}{c}\text { Time } \\
\text { Management }\end{array}$ \\
\hline $\begin{array}{l}\text { Mathematical } \\
\text { Reasoning }\end{array}$ & $\begin{array}{l}\text { Written } \\
\text { Expression }\end{array}$ & $\begin{array}{c}\text { Service } \\
\text { Orientation }\end{array}$ & \\
\hline \multirow[t]{2}{*}{ Visualisation } & ICT Literacy & $\begin{array}{l}\text { Training and } \\
\text { Teaching }\end{array}$ & \\
\hline & & Others & \\
\hline Physical Abilities & Process Skills & Systems Skills & Technical Skills \\
\hline Physical Strength & Active Listening & $\begin{array}{c}\text { Judgement and } \\
\text { Decision- Making }\end{array}$ & $\begin{array}{c}\text { Equipment } \\
\text { Maintenance and } \\
\text { Repair }\end{array}$ \\
\hline \multirow[t]{5}{*}{$\begin{array}{l}\text { Manual Dexterity } \\
\text { and Precision }\end{array}$} & Critical Thinking & Systems Analysis & $\begin{array}{l}\text { Equipment } \\
\text { Operation and } \\
\text { Control }\end{array}$ \\
\hline & $\begin{array}{l}\text { Monitoring Self } \\
\text { and Others }\end{array}$ & & Programming \\
\hline & & $\begin{array}{c}\text { Complex } \\
\text { Problem-Solving } \\
\text { Skills }\end{array}$ & Quality Control \\
\hline & & $\begin{array}{c}\text { Complex } \\
\text { Problem- Solving }\end{array}$ & $\begin{array}{c}\text { Technology and } \\
\text { User Experience } \\
\text { Design }\end{array}$ \\
\hline & & & Troubleshooting \\
\hline
\end{tabular}


On this note, mapping the critical skills identified by the World Economic Forum and the skills required for law graduates would reveal the skills gap needed for law graduates to survive in the future. It is noted that MQA focuses more on professional and disciplinespecific skills, and out of the 16 skills identified only two relate to generic skills, i.e. self-management and oral communication. MQA may need to pay more attention to 4 other skills required for the future workforce, i.e. social skills, resource management skills, technical skills and system skills. There should be more focus on reskilling as IR4.0 has caused not only business transformation and job opportunities but it has also mandated educational transformation. More emphasis should be made on social and technical skills that would facilitate the process of adaptation and evolution in the current environment. Much like the theory of evolution, those who fail to adapt to changes in the environment will not survive and may die out of isolation. Many law schools have moved their graduate attributes to generic skills. For example, the University of Canterbury professes the following graduate attributes: employable, innovative and enterprising, bicultural competence and confidence, globally aware and community engagement. These are critical skills that graduates require in an eco-system that is being massively disrupted by the advanced technological revolution.

\section{BODY OF KNOWLEDGE}

The advances in information technology have disrupted the national legal framework designed for the physical world (Botta, de Donato, Persico \& Pescape, 2016). These come first in terms of governance and institutional involvement. What are the norms to be standardized, what institutions should champion norm setting and through which platform? (Cath, 2018). In many ways, IoT challenges or disrupts traditional norms.

Second, in terms of rights and liabilities, with the wide application of autonomous systems, robots and artificial intelligence, unresolved legal issues arise in the areas of data protection, confidentiality, cloud computing, data ownership, product liability, contractual liability, IT security, labour and intellectual property (Leenes et al., 2017). 
Third, it is expected that the fusion of cyberspace and the real world will assist in generating quality data to create new values and solutions to resolve challenges. The ensuing issue will be the ownership of innovative processes and products developed through Society 5.0 and IR4.0 (Liao, Deschamps, Rocha Loures \& Pierin Ramos, 2017).

A plethora of legal issues arise from the adoption of artificial intelligence in legal practice (Madakam et al., 2015). The term artificial intelligence itself has been the subject of various interpretations. One definition is "the ability of machines to execute tasks and solve problems in ways normally attributed to humans" (Atabekos \& Yestrebov, 2018). A lot of information gathered in the course of litigation may remain beyond the capability of AI to parse as the data will largely be unstructured.

In terms of contractual rules, would the advice given by the roboadvisors bind the developers of the algorithm using normal agency rules? (Durovic \& Janssen, 2018). Would flaws in algorithms give rise to product liability claims? If the advice given is a result of the negligence of the developer in the formulation of the algorithm, can the algorithm developer be liable to negligent misstatement. What if advice is injurious to the business goodwill of a party? Can a suit for injurious falsehood lie? And if it affects the reputation of a particular trader, can a suit of defamation be raised? (Lewis, Sanders \& Carmody, 2019). We can think of other potential legal liabilities such as vicarious liability of the employer of the developer of the autonomous system. In the early days of the Internet, we heard of possible defences being put up for criminal offences such as, "it is not me but it is the Trojan horse"? In the context of autonomous systems, could the claim that "it is not me but it is the algorithm" be an acceptable defence?

Undeniably, legal rules written for the brick and mortar world need to be revisited in this information era (Kingston, 2016). We have to be mindful of three major challenges when framing new norms to cover new legal issues arising from the use of bots. Firstly, as these autonomous systems may be ubiquitous and pervasive, can someone be held responsible for acts and conducts that take place as his/her participation is never dependent upon consent. Secondly, the nature 
of interconnectivity and real-time data itself challenges the notion of sovereignty. The traditional concept of sovereignty which is based on the concept of control and custodianship under political science is no longer relevant in IR4.0. Thirdly, as most nations can only control acts and conducts occurring within their territory, there is a problem with cross-border enforcement. Interconnectivity and realtime data implicate cross-border data flow which ultimately affects the CIA (confidentiality, integrity and availability) principle inherent in information security (Maple, 2017).

The autonomous systems also make possible the creation of a whole range of reports, essays, diagrams and artistic works, and the ensuing issues would be the copyright ownership of these works of expression (Lewis et al., 2018). Would we then, be willing to confer copyright to non-human authorship? The history of copyright has shown that the courts have been quite reluctant to accord copyright to non-human entities. In Telstra Corporation Ltd \& Anor v Phone Directories Company Ptd \& Ors [2010] FCAC 149, it was found by the Federal Court that databases developed through systems without the involvement of human individuals are not considered copyrightable. This is because the notion of authorship is not tied up to individual authors. The position is surprisingly not new in copyright. Twenty years ago, the law was revised to provide for computer-aided design, where copyright is accorded to the person responsible for the creation of the work. Where there is no individual author involved then there is no copyright over the work.

All this literature alludes to the fact that IoT-related technologies disrupt the existing traditional legal framework created in the brick and mortar environment. One could imagine the kind of novel issues that could crop up in the future and the content of the body of knowledge required for legal competency would need to be revisited in the age of IR4.0.

\section{CONCLUSION}

It has been predicted that the range of works that could be replaced by automation in Malaysia is as high as $51.4 \%$. It is high time that we, in the educational institution, take stock of what is happening 
and revisit the aims and objectives of legal education. The traditional emphasis of law schools in creating law graduates who think like lawyers definitely needs to change with the changing of times. We need to bridge the gap between what the future workplace requires and what we currently produce in terms of law graduate training. The adaptation involves not only the skill sets but also the body of knowledge in a law curriculum. In this paper, some of the points raised in academic discourse on the novel challenges posed by IR4.0 have been touched on. In this process, academics have a role to play, not only in their classrooms but also in assisting the policy-makers in making the adaptation and evolution come to fruition.

First, some of the generic skills imparted by the law schools can readily be replaced by the autonomous system. Of particular concerns are repetitive and routine activities such as discovery of statutory materials, court reports and judgements which are commonly done by chambering students or junior legal assistants. Preparing court documents, conveyancing, banking and land documents, standard contracts or other official documents for purposes of legal compliance could also easily be undertaken by computer systems. Simple literal analysis of the legislative provisions and basic doctrinal analysis of reported judgements could also be easily done by a computer system that has the ability to compress, digest and synthesize legal materials in a short time frame compared to a human being.

On that basis, law schools should emphasize more on the complex skills that could not be easily performed by computers. These include a wide range of lawyer skills such as mediation, negotiation, court prosecution, advocacy, witness examination, plea mitigation or family counselling. These skills that dwell on conscience, emotion, empathy, compassion, preference, ethics and morality would be the differentiating factor between us humans and the autonomous systems and bots. It is on issues pertaining to the heart or qalb (the conscience) that needs to be strengthened if lawyers want to keep themselves relevant in this IR4.0 era. Even if there may be permutations of predictive software that could be used for purposes of sentencing, they at best could be seen only as assistance and not the primary method of sentencing.

The MQA Standards on the Teaching of Law and Shariah (MQA, 2015) would need to be revised so that the required body of 
knowledge is constantly updated to follow changes in legal principles as a result of technological advancement. Law students would also need to expect further disruption of legal principles as many of the consequences of artificial intelligence, data analysis and Internet of Things are currently unknown. The current way in which policy changes are formulated which requires a top-down direction from policy-makers may not be good enough or fast enough to anticipate the changes required to resolve unique problems posed by the digitalised era. Lawyers and judges would have to fill the vacuum by extending the traditional legal principles to these new issues. The body of knowledge that is being taught in the law schools may be outdated by the time the law students graduated.

The skill sets needed for law students to survive in the IR4.0 era would also be different than what law schools are accustomed to. Lawyers would need to be prepared for further re-skilling in the form of continuous training to keep them up to date to technological changes.

More fundamentally, to survive the IR4.0 era, the focus should not be primarily on professional legal skills as identified by the Legal Profession Qualifying Board as well as the Malaysian Qualifications Agency. A whole range of generic social, technical and system skill, as identified by the World Economic Forum, would have to supplement the legal skills for the lawyers to survive in this fastchanging world.

\section{REFERENCES}

Alarie, B., Niblett, A., \& Yoon, A. (2017). How artificial intelligence will affect the practice of law. Retrieved from https:// ssrn.com/abstract $=3066816$ or http://dx.doi.org/10.2139/ ssrn.3066816.

Ashley, K., Branting, K., Margolis, H., R., Sunstein, C. R. (2001). Legal reasoning and artificial intelligence: How computers "think" like lawyers. The University of Chicago Law School Roundtable, 8(1), Article 2.

Atabekos, A., \& Yestrebov, O. (2018). Legal status of artificial intelligence across countries: Legislation on the move. European Research Studies Journal, XXI (4). 
Australian Chamber of Commerce and Industry. (2017). Digital Economy: Opening up the conversation. Retrieved from https://www.industry.gov.au/innovation/Digital-Economy/ Documents/Digital-Economy-Strategy-Consultation-Paper. pdf.

Banerjee, P. M., \& Belson, G. (2015). Digital education 2.0: From content to connections. Retrieved from https://www2.deloitte. $\mathrm{com} /$ us/en/insights/deloitte-review/issue-16/future-digitaleducation-technology.html.

Botta, A., de Donato, W., Persico, W., \& Pescape, A. (2016). Integration of cloud computing and Internet of things: A survey. Future Generation Computer Systems, 56, 684-700.

Brennan-Marquez, K., \& Henderson, S. E. (2019). Artificial intelligence and role reversible judgement. 109 J. Crim. L, \& Criminology, 137.

Campbell, R. W. (2014). The end of law schools: Legal education in the era of legal service business. Mississippi Law Journal, $85(1)$.

Carraz, R., \& Harayama, Y. (2018). Japan's innovation systems at the crossroads: Society 5.0. Digital Asia, 33-4. Retrieved from https://www.kas.de/documents/288143/4843367/panorama digital_asia_v3a_Carraz_Harayama.pdf/b57f6b67-f317cfc5-010c-4ee501 c3a398..https://www.industry.gov.au/ innovation/Digital-Economy/Documents/Digital-EconomyStrategy-Consultation-Paper.pdf.

Cath, C. (2018). Governing artificial intelligence: Ethical, legal and technical opportunities and challenges. Philos Trans a Math Phys Eng Sci. Nov 28, 376(2133):20180080.

Christensen, S., \& Kift, S. (2000) Graduate attributes and legal skills: Integration or disintegration? Legal Education Review, $8(11), 2$.

Committee for Economic Development of Australia (CEDA). (2015). Australia's future workforce. Retrieved from https:// www.ceda.com.au/Research-and-policy/All-CEDA-research/ Research-catalogue/Australia-s-future-workforce.

Deloitte Digital. (2015). Higher education - Digital growth and innovation. Retrieved from https://www2.deloitte.com/us/ en/insights/deloitte-review/issue-16/future-digital-educationtechnology.html.

Durovic, M., \& Janssen, A. (2018). The formation of smart contracts and beyond: Shaking the Fundamentals of Contract Law. Retrieved from www.researchgate.net. 
Fukuyama, M. (2018). Society 5.0: Aiming for a new human-centered society. Japan Spotlight, 47-50. Retrieved from https://www. jef.or.jp/journal/pdf/220th_Special_Article_02.pdf.

Kingston, J. (2016). Artificial Intelligence and Legal liability, from book Research and Development in Intelligent Systems XXXIII: Incorporating Applications and Innovations in Intelligent Systems XXIV, 269-279. Retrieved from www. researchgate.net.

Leenes, R., Palmerini, E., Koops, B-J.,, Bertolini, A., Salvini, P., \& Lucivero, F. (2017). Regulatory challenges of robotics: Some guidelines for addressing legal and ethical issues. Law, Innovation and Technology, 9(1), 1-44.

Lewis, S. C., Sanders, A. K., \& Carmody, C. (2019). Libel by algorithm? Automated journalism and the threat of legal liability. Journalism \& Mass Communication Quarterly, 96(1), 60-81. Retrieved from https://doi. org/10.1177\%2F1077699018755983.

Liao, Y. Deschamps, F., Rocha Loures, E. F., \& Pierin Ramos, L. F. (2017). Past, present and future Industry 4.0 - A systematic literature review and research agenda proposal. International Journal of Production Research. Retrieved from http://dx.doi. org/10.1080/00207543.2017.1308576.

Madakam, S., Ramaswamy, R., Tripathi, S. (2015). Internet of Things (IoT): A literature review. Journal of Computer and Communications, 3, 164-173.

Madison, M. J. (2018). An invitation regarding law and legal education, and imagining the future. $U$ of Pittsburgh Legal Studies Research Paper No 2018-03. Retrieved from https:// papers.ssrn.com/sol3/papers.cfm?abstract_id $=3122624$.

Maple, S. (2017). Security and privacy in the Internet of Things. Journal of Cyber Policy, 2(2), 155-184.

MIMOS. (2015) National Internet of Things (IoT) Strategic roadmap: A summary. Retrieved from http://www.mimos. my/iot/National_IoT_Strategic_Roadmap_Summary.pdf.

Malaysian Qualifications Agency (MQA). (2015). Programme Standards: Law and Shariah Law. Malaysia: Malaysian Qualifications Agency.

Payton, A. (2017) Skilling for Tomorrow. $26^{\text {th }}$ National VET Research Conference 'No Frills'. Retrieved from https://www.ncver. edu.au/research-and-statistics/publications/all-publications/ skilling-for-tomorrow. 
Penprase, B. E. (2018). The Fourth Industrial Revolution and Higher Education, Higher Education in the Era of the Fourth Industrial Revolution. In Nancy W. Gleason (Ed.), Higher Education in the Era of the Fourth Industrial Revolution. Palgrave Macmillan.

Raskin, M. (2017). The law and legality of smart contracts. 1 Geo. L. Tech. Rev, 305.

Simshaw, D. (2018). Ethical issues in robo-lawyering: The need for guidance on developing and using artificial intelligence in the practice of law. Hastings Law Journal, 70, 173 - 213.

Smart Nation and Digital Government Office. (2018). Retrieved fromhttps://www.smartnation.sg/docs/default-source/defaultdocument-library/smart-nation strategy_nov2018.pdf.

State of Wisconsin v Eric L. Loomis (No 2015AP157-CR). Retrieved from https://www.wicourts.gov/sc/opinion/ DisplayDocument.pdf?content $=$ pdf\&seqNo $=171690$

Susskind, R. (1996). The future of law: The challenges of information technology. UK: Oxford University Press.

Susskind, R. (2015). The future of the professions: How technology will transform the work of human experts. UK: Oxford University Press.

Sharon, C., \& Sally, K. (2000). Graduate attributes and legal skills: Integration or disintegration? Legal Education Review, 8(11) (2).

Telstra Corporation Ltd \& Anor v Phone Directories Company Ptd $\&$ Ors [2010] FCAC 149.

The World Economic Forum. (2016). The future of jobs: Employment, skills and workforce strategy for the fourth industrial revolution. Retrieved from http://www3.weforum.org/docs/ WEF_Future_of_Jobs.pdf.

World Economic Forum. (n.d). The fourth industrial revolution by Klaus Schwab. Retrieved from https://www.weforum.org/ about/the-fourth-industrial-revolution-by-klaus-schwab. 